Jurnal Iqra' Vol.3. No.1, Januari - Juni 2009

\title{
PENGARUH PEMANFAATAN TEKNOLOGI INFORMASI DAN MOTIVASI BELAJAR TERHADAP PERILAKU BELAJAR SISWA
}

\author{
Oleh: Abdul Haris Abdullah*
}

Abstrak

This research aimed to describe: (1) the relationship between the utilization of Information Technology, learning motivation, and learning behavior; (2) the relationship of the utilization of Information Technology and learning motivation, individually or combined toward the learning behavior of the students of SMK in Manado City.

The research sample was 84 students chosen proportionally from the total population of 530 students scattered at 4 SMK in Manado City. This research applied survey method with data collecting technique through questionnaires which had been tested before for their validity and reliability. Furthermore, the collected data was analyzed by computer, using SPSS 16 for Windows 2007.

Based on the research analysis, the following findings were: (1) Relationship was found between the utilization of Information Technology, learning motivation, and learning behavior; (2) significant impact was found between the utilization of information technology and learning motivation toward learning behavior of the students of SMK in Manado City, either individually or combined.

Kata Kunci: Information Technology, Motivation, Learning behaviour

\section{Pendahuluan}

Metode Pemerintah pusat mengalokasikan dana total $\mathrm{Rp} 500$ miliar untuk membantu pemerintah daerah memperbanyak pembangunan Sekolah Menengah Kejuruan (SMK) di berbagai daerah. Depdiknas siap membantu melakukan studi kelayakan bagi Pemda yang berniat untuk mengubah SMA menjadi SMK serta mengembangkan SMKSMK baru sesuai dengan target pemerintah hingga 2009 nanti. Depdiknas mengharapkan perbandingan SMK dan SMA 70:30 pada 2009. Saat ini, rasio SMK dengan SMA masih 30:70. Target pada 2008 menjadi 40:60 dan pada 2009 rasio perbandingan SMK dengan SMA menjadi 70:30. Sedangkan, selisih siswa SMA dengan SMK saat ini sebanyak dua juta orang. Secara perlahan-lahan dengan analisis yang tepat peralihan sekolah itu akan dilakukan. Untuk membuat SMK yang bermutu serta lulusannya bisa diandalkan di pasar

* Penulis adalah dosen tetap pada Jurusan Tarbiyah Program Studi Pendidikan Agama Islam STAIN Manado. 
kerja membutuhkan Rp 22 miliar. SMK untuk bisa disebut bermutu minimal harus membangun fasilitas seperti laboratorium. Tujuan untuk terus memperbanyak SMK karena lulusan SMK lebih mudah masuk ke pasar kerja ketimbang lulusan SMA karena umumnya mata pelajaran di SMK sudah disertai dengan praktik keterampilan. Siswa SMA yang tidak bekerja atau tidak melanjutkan ke perguruan tinggi menyumbang jumlah pengangguran yang saat ini jumlahnya mencapai 40 juta orang. Harapan dengan mengubah SMA ke Sekolah Menengah Kejuruan (SMK) supaya mereka bisa bekerja atau membuka lapangan kerja sendiri. Depdiknas siap membantu daerah-daerah yang ingin mendirikan SMK, baik berupa bantuan guru-guru maupun program, kurikulum, dan bantuan menentukan jenis SMK yang cocok untuk suatu daerah. Namun demikian, SMK itu juga harus sesuai dengan potensi wilayah dan kebijakan daerah itu di masa mendatang. (http://www.indonesia.go.id/id - REPUBLIK INDONESIA Powered by Joomla Generated: 25 June, 2008).

Memperhatikan besarnya perhatian pemerintah terhadap SMK saat ini merupakan peluang bagi daerah-daerah melakukan perencanaan strategis mengelolah SMK menjadi sekolah yang menelorkan anak didiknya siap pakai di lapangan kerja atau sedapat mungkin menciptakan lapangan kerja secara mandiri.

Permasalahan yang timbul kemudian adalah apakah antara harapan pemerintah yang menginginkan berkurangnya pengangguran lulusan sekolah menengah sejalan dengan perilaku belajar (output pendidikan) yang dihasilkan SMK? Apakah siswa SMK memiliki motivasi belajar yang tinggi serta sudahkah siswa SMK memenuhi kompetensi dalam memanfaatkan teknologi informasi sebagai prasyarat kerja di era global ini?.

\section{Pembahasan}

\section{a. Perilaku Belajar}

Perilaku belajar yang dimaksudkan adalah berkaitan dengan bagaimana cara individu bertindak di dalam lingkungan sekolah serta pengaruh tindakan sebagai pola berperilaku yang berhubungan dengan sikap ${ }^{1}$.

Perilaku umumnya dapat diperkirakan jika kita tahu bagaimana orang tersebut menyikapi situasi dan apa yang penting baginya. Meski perilaku seseorang mungkin tampak tidak rasional bagi orang lain, terdapat alasan untuk meyakini bahwa perilaku tersebut biasanya dimaksudkan agar rasional dan dianggap rasional oleh mereka. Seseorang ketika mengamati sering melihat satu perilaku tak rasional karena pengamat itu tidak mempunyai informasi yang sama atau tidak menyikapi lingkungan dengan cara yang sama dengan yang berperilaku ${ }^{2}$.

${ }^{1}$ Barry Cushway \& Derek Lodge, Perilaku dan Desain Organisasi, (Jakarta : Alex Komputindo, 1993), h. 1.

2 Stephen Robins, Perilaku Organisasi, alih bahasa Ahmad Fauzi, Edisi X, (Jakarta : PT. Indeks, 2006), h. 11 
Perilaku dalam penggunaan secara umum bersinonim dengan aktivitas, aksi, gaya, respons, dan reaksi. Dengan kata lain perilaku merupakan segala sesuatu yang dikatakan atau dikerjakan oleh seseorang dan bahwa perilaku seseorang dipengaruhi oleh pengalaman masa lalu, masa kini, dan pandangan terhadap masa yang akan datang. Sumber daya penyebab semua perilaku berada dalam diri manusia itu sendiri secara internal dan tindakan manusia pada dasarnya merupakan reaksi-reaksi terhadap lingkungan internal maupun eksternal yang melingkupinya.

\section{b. Pemanfaatan Teknologi Informasi}

Teknologi Informasi dan Komunikasi (CIT) merupakan suatu kebutuhan menuju "Innovative School" karena dengan penggunaan CIT diharapkan adanya peningkatan mutu belajar/ mengajar, peningkatan produktivitas/ efisiensi dan akses, peningkatan sikap belajar yang positif, pengembangan professional/ staff dan adanya peningkatan profil/ pengenalan. Kelima hal tersebut merupakan harapan sekaligus kebutuhan yang menjadi dasar perlunya penerapan CIT di sekolah. Dengan demikian diharapkan sekolah mengalami perubahanperubahan yang sesuai dengan tuntutan global tetapi tetap searah dengan visi dan misinya yang dikorelasikan dengan kebutuhan sekolah dan daerah ${ }^{3}$.

Pendidikan memegang peranan penting dalam mempersiapkan sumber daya manusia yang berkualitas. Oleh karena itu pendidikan hendaknya dikelola, baik secara kualitas maupun kuantitas. Hal tersebut bisa tercapai bila pebelajar dapat menyelesaikan pendidikan tepat pada waktunya dengan hasil belajar yang baik. Hasil belajar seseorang ditentukan oleh berbagai faktor yang mempengaruhinya. Salah satu faktor yang ada di luar individu adalah tersedianya bahan ajar yang memberi kemudahan bagi individu untuk mempelajarinya, sehingga menghasilkan belajar yang lebih baik. Selain itu juga gaya belajar atau learning style adalah suatu karakteristik kognitif, afektif dan perilaku psikomotoris, sebagai indikator yang bertindak yang relatif stabil untuk pebelajar merasa saling berhubungan dan bereaksi terhadap lingkungan belajar. Gaya belajar mengacu pada cara belajar yang lebih disukai pebelajar. Umumnya, dianggap bahwa gaya belajar seseorang berasal dari variabel kepribadian, termasuk susunan kognitif dan psikologis latar belakang sosio cultural, dan pengalaman pendidikan. Keanekaragaman Gaya belajar mahasiswa perlu diketahui pada awal permulaannya diterima pada suatu lembaga pendidikan yang akan ia jalani. Hal ini akan memudahkan bagi pebelajar untuk belajar maupun pembelajar untuk mengajar dalam proses pembelajaran. Pebelajar akan dapat belajar dengan baik dan hasil belajarnya baik, apabila ia mengerti gaya belajarnya. Hal tersebut memudahkan pembelajar dapat menerapkan pembelajaran dengan mudah dan tepat. Meningkatkan kemampuan intelegensinya yang sangat mempengaruhi hasil belajar. Hasil belajar merupakan gambaran tingkat penguasaan mahasiswa terhadap sasaran belajar pada topik bahasan yang

\footnotetext{
${ }^{3}$ http://media.diknas.go.id/media/dokument/5448.pdf.
} 
dieksperimenkan, yang diukur dengan berdasarkan jumlah skor jawaban benar pada soal yang disusun sesuai dengan sasaran belajar ${ }^{4}$.

Karakteristik teknologi informasi dalam pendidikan :

1. Memungkinkan adanya penyebaran informasi secara luas, merata, cepat. seragam, dan terintegrasi sehingga pesan yang disampaiakn sesuai dengan isi yang dimaksud.

2. Dapat menyajikan materi secara logis, ilmiah, dan sistematis serta mampu melengkapi, menunjang, memperluas konsep-konsep,prinsip-prinsip atau proposisi materi pelajaran.

3. Menjadi partner guru dalam rangka melvujudkan proses mengajar yang efektif, efesien, dan produktif sesuia dengan kebutuhan dan tuntunan anak didik.

4. Dapat dijadikan sebagai sumber belajar yang dapat menyajikan materi secara lebih menarik.

5. Berperan penuh dalam proses belajar mengajar walaupun tidak menggantikan posisi guru secara mutlak atau mengubah pola pengajaran tradisional $^{5}$.

\section{c. Motivasi Belajar}

Motivasi lebih dekat kepada mau melaksanakan tugas dalam mencapai tujuan. Motivasi adalah kekuatan, baik dari dalam maupun dari luar yang mendorong seseorang untuk mencapai tujuan yang telah ditetapkan sebelumnya ${ }^{6}$.

Hal ini sesuai dengan pendapat David McClelland, Edward Murray, Miller dan Gordon sebagaimana dikutip Anwar Prabu Mangkunegara yang menyimpulkan bahwa "ada hubungan yang positif antara motivasi dengan pencapaian prestasi". Artinya, individu yang mempunyai motivasi tinggi cenderung memiliki prestasi tinggi dan sebaliknya mereka yang prestasi kerjanya rendah disebabkan karena motivasi kerja rendah. Oleh karena itu, pimpinan organisasi harus berusaha keras mempengaruhi motivasi seluruh individu. organisasi agar mereka memiliki motivasi berprestasi tinggi ${ }^{7}$.

Motivasi adalah proses kesediaan melakukan usaha tingkat tinggi untuk mencapai sasaran, yang dikondisikan oleh kemampuan. Reward merupakan salah satu pendorong kepada motivasi yang tinggi. Meskipun secara umum motivasi merujuk ke upaya yang dilakukan guna mencapai setiap sasaran, di sini kita merujuk ke sasaran individu karena fokus kita adalah perilaku yang berkaitan dengan belajar. Ada tiga unsur kunci dalam

\footnotetext{
${ }^{4}$ http://re-searchengines.com/art05-94.html

${ }^{5}$ Sudarwan Danim, Inovasi Pendidikan, ( T,t: Pustaka Setia, 2002), h. 25 .

${ }^{6}$ Kambey, Daniel C, Manajemen Sumber Daya Manusia, cet. Pertama,( Manado : Yayasan
} Triganesa Nusantara, 1999), h. 134

${ }^{7}$ Anwar Prabu Mangkunegara, Perilaku dan Budaya organisasi, (T.t: Rerfika Aditama, 2005), h. 18. 
definisi itu: upaya, sasaran dan kebutuhan.Unsur upaya, merupakan ukuran intensitas atau dorongan. Seseorang yang termotivasiakan berusaha keras. Kebutuhan mengacu ke keadaan batin yang membuat hasil. Kebutuhan menciptakan rangsangan ${ }^{8}$.

\section{d. Penelitian Relevan}

Guru Besar UPI Bandung/Ketua Umum PB PGRI/Anggota DPD-RI dalam Makalah Seminar "Pemanfaatan Teknologi Informasi dan Komunikasi untuk Pendidikan Jarak Jauh dalam Rangka Peningkatan Mutu Pembelajaran", diselenggarakan oleh Pustekkom Depdiknas, tanggal 12 Desember 2006 di Jakarta. Mengemukakan bahwa Perkembangan teknologi informasi dan komunikasi (TIK) telah memberikan pengaruh terhadap dunia pendidikan khususnya dalam proses pembelajaran. Menurut Rosenberg (2001), dengan berkembangnya penggunaan TIK ada lima pergeseran dalam proses pembelajaran yaitu: (1) dari pelatihan ke penampilan, (2) dari ruang kelas ke di mana dan kapan saja, (3) dari kertas ke "on line" atau saluran, (4) fasilitas fisik ke fasilitas jaringan kerja, (5) dari waktu siklus ke waktu nyata. Komunikasi sebagai media pendidikan dilakukan dengan menggunakan media-media komunikasi seperti telepon, komputer, internet, e-mail, dsb. Interaksi antara guru dan siswa tidak hanya dilakukan melalui hubungan tatap muka tetapi juga dilakukan dengan menggunakan media-media tersebut. Guru dapat memberikan layanan tanpa harus berhadapan langsung dengan siswa. Demikian pula siswa dapat memperoleh informasi dalam lingkup yang luas dari berbagai sumber melalui cyber space atau ruang maya dengan menggunakan komputer atau internet. Hal yang paling mutakhir adalah berkembangnya apa yang disebut "cyber teaching" atau pengajaran maya, yaitu proses pengajaran yang dilakukan dengan menggunakan internet. Istilah lain yang makin poluper saat ini ialah e-learning yaitu satu model pembelajaran dengan menggunakan media teknologi komunikasi dan informasi khususnya internet. Menurut Rosenberg (2001; 28), e-learning merupakan satu penggunaan teknologi internet dalam penyampaian pembelajaran dalam jangkauan luas yang belandaskan tiga kriteria yaitu: (1) e-learning merupakan jaringan dengan kemampuan untuk memperbaharui, menyimpan, mendistribusi dan membagi materi ajar atau informasi, (2) pengiriman sampai ke pengguna terakhir melalui komputer dengan menggunakan teknologi internet yang standar, (3) memfokuskan pada pandangan yang paling luas tentang pembelajaran di balik paradigma pembelajaran tradisional. Saat ini e-learning telah berkembang dalam berbagai model pembelajaran yang berbasis TIK seperti: CBT (Computer Based Training), CBI (Computer Based Instruction), Distance Learning, Distance Education, CLE (Cybernetic Learning Environment), Desktop Videoconferencing, ILS (Integrated Learning Syatem), LCC (Learner-Cemterted Classroom), Teleconferencing, WBT (Web-Based Training), dsb.

Sari Sunindar Auliyawati tahun 2005 meneliti tentang: Efektifitas Penerapan Metode Tutor Sebaya Dalam Kelompok Kecil Untuk Meningkatkan Prestasi Belajar

${ }^{8}$ Stephen P. Robbins \& Mary Coulter, Manajemen, jilid 2,s alih bahasa Harry Slamet, Edisi VIII, (T.t: PT. Indeks, 2007), h. 129 
Akuntansi Pokok Bahasan Jurnal Khusus Perusahaan Dagang Pada Siswa Kelas XI IS SMA Negeri I Karanganom Tahun Ajaran 2006/2007.Jurusan Akuntansi Fakultas Ekonomi Universitas Negeri Semarang. Menurut penelitiannya bahwa Keberhasilan siswa dalam belajar dipengaruhi oleh beberapa faktor, salah satunya adalah metode yang digunakan guru dalam mengajar. Pada kenyataannya, dalam pembelajaran masih menggunakan metode konvensional, sehingga siswa kurang aktif dalam pembelajaran dan prestasi belajar kurang memuaskan. Siswa dapat mencapai prestasi belajar yang maksimal bila seorang guru tepat dalam menerapkan metode mengajar. Untuk itu diperlukan suatu metode pembelajaran yang inovatif dan mampu meningkatkan keaktifan serta prestasi belajar siswa.

Herliani Raden Roro dalam http://www.digilib.ui.edu/opac/ themes /libri2 /detail.jsp?id meneliti hubungan antara sikap terhadap sains dan prestasi belajar sains pada siswa sekolah menengah pertama di Indonesia berdasarkan data TIMSS 2003 bahwa Keberhasilan prestasi belajar Sains seorang siswa dipengaruhi banyak faktor. Salah satu faktor internal yang diperkirakan ikut mempengaruhi hal tersebut adalah sikap (attitude) siswa terhadap obyek yang berkaitan dengan pelajaran sains. sikap terhadap sekolah, sikap terhadap biologi, sikap terhadap ilmu bumi dan sikap terhadap fisika adalah sikap-sikap yang ikut mempengaruhi sikap terhadap sains yang selanjutnya akan mempengaruhi prestasi belajar Sains.

Proses belajar mengajar tidak bisa terlepas dari berbagai faktor yang mempengaruhi dan menunjang keberlangsunganya. Bagi lembaga pendidikan, setelah menentukan program-progam dan kurikulum pendidikan, haruslah mempunyai prinsip dalam menentukan arah tekhnis pelaksanaan cita-cita dari progam dan kurikulum yang telah dicanangkan. Salah satu penunjang utamanya adalah, adanya motivasi belajar bagi peserta didik yang terstruktur dan terkonstruk dengan baik.

\section{e. Pengajuan Hipotesis}

a. Hipotesis 1

Terdapat pengaruh Pemanfaatan Teknologi Informasi dengan Perilaku Belajar

b. Hipotesis 2

Terdapat pengaruh Motivasi Belajar dengan Perilaku Belajar

c. Hipotesis 3

Terdapat pengaruh Pemanfaatan Teknologi Informasi dan Motivasi Belajar secara bersama-sama dengan Perilaku Belajar. 
Jurnal Iqra' Vol.3. No.1, Januari - Juni 2009

\section{f. Metodologi}

\section{a. Objek Penelitian}

Dalam penelitian ini objeknya adalah siswa SMK di Kota Manado.

\section{b. Populasi dan Sampel}

Populasi adalah totalitas semua nilai yang mungkin baik hasil menghitung ataupun pengukuran, kuantitatif maupun kualitatif dari karakteristik tertentu mengenai sekumpulan objek yang lengkap dan jelas yang ingin dipelajari sifat-sifatnya.

Sampel adalah bagian dari populasi, sebagian dari populasi yang diambil sebagai sumber data dan dapat mewakili seluruh populasi. Apabila populasi kurang dari 100, lebih baik diambil semuanya, sehingga penelitiannya merupakan penelitian populasi. Selanjutnya jika subjeknya besar, dapat diambil 10\% - 15\% atau 20\% - 25\% atau lebih ${ }^{9}$.

Memperhatikan hal di atas, maka penelitian dalam penelitian ini karena jumlah populasinya lebih dari 100 maka penarikan sampelnya dilakukan secara acak (random sampling). Teknik pengambilan sampelnya menggunakan rumus dari Taro Yamane (dalam Riduwan \& Engkos Achmad Kuncoro, 2007:210), sebagai berikut:

$$
\mathrm{n}=\frac{\mathrm{N}}{\mathrm{Nd}^{2}+1}
$$

Keterangan :

$\mathrm{n} \quad=$ Jumlah sampel

$\mathrm{N}=$ Jumlah populasi

$\mathrm{Nd}^{2}=$ Presisi (ditetapkan 10\% dengan tingkat kepercayaan 95\%)

Berdasarkan rumus diperoleh jumlah sampel sebagai berikut:

$$
\mathrm{n}=\frac{\mathrm{N}}{\mathrm{Nd}^{2}+1}=\frac{530}{(530) \cdot 0,1^{2}+1}=\frac{530}{6,3}=84,12=84 \text { responden }
$$

${ }^{9}$ Suharsimi Arikunto, Prosedur Penelitian Suatu Pendekatan Praktek, (Jakarta : Rineka Cipta, 2004),h. 117-120. 


\section{g. Definisi Operasional}

\section{Perilaku Belajar}

Dalam penelitian ini perilaku belajar siswa adalah bermuara pada usaha yang dapat dia lakukan dalam pergaulan sekolah dan lingkungan lainnya untuk mencapai prestasi dan pengakuan prestasi dari masyarakat dan sekolah dimana dia menuntut ilmu.

Faktor pembentuk perilaku belajar. Faktor tersebut adalah faktor genetik, faktor lingkungan, faktor pendidikan dan faktor pengalaman. Faktor genetik adalah segala hal yang oleh seseorang dibawa sejak lahir dan bahkan pula merupakan "warisan" dari kedua orang tuanya. Faktor lingkungan adalah situasi dan kondisi yang dihadapi oleh seseorang, pada masa usia muda dalam rumah dan lingkungan yang lebih luas, terutama lingkungan sekolah dan lingkungan masyarakat dekat yang dilihat dan dihadapi sehari-hari. Faktor pendidikan adalah usaha sadar dan sistematis yang berlangsung seumur hidup, dalam rangka mengalihkan pengetahuan kepada seseorang. Pendidikan harus disadari, bahwa sasaran pendidikan tidak semata-mata pengalihan pengetahuan dan keterampilan. Salah satu bagian yang teramat penting dari upaya pendidikan adalah pembinaan watak (character building). Asumsi dasar yang biasanya dipergunakan dalam memanfaatkan pendidikan sebagai salah satu faktor pembentuk perilaku belajar siswa, adalah para siswa secara individual pada umumnya ingin memperoleh gambaran yang jelas tentang: (a) bagaimana prestasi belajarnya akan meningkat; (b) kesempatan-kesempatan apa yang terbuka untuk mengembangkan atau meningkatkan perilaku belajar yang mampu mencapai prestasi.

\section{Motivasi Belajar}

Dalam penelitian ini motivasi belajar adalah kondisi yang mampu membangkitkan baik dari dalam maupun dari luar diri siswa yang mencakup motif, harapan, dan penghargaan dalam menunjang belajarnya.

Motivasi adalah suatu faktor yang mendorong seseorang untuk melakukan suatu perbuatan atau kegiatan tertentu. Motivasi diartikan pula sebagai faktor pendorong perilaku seseorang. Setiap tindakan yang dilakukan oleh seorang pasti memiliki sesuatu faktor yang mendorong perbuatan tersebut. Suatu model yang sederhana menyatakan bahwa motivasi belajar itu timbul dari adanya kebutuhan manusia itu sendiri. Seseorang akan terdorong untuk melakukan suatu tindakan karena dia merasa memiliki kebutuhan yang ingin dipenuhinya. Kebutuhan ini bisa bermacam-macam mulai dari yang paling dasar yang bersifat fisik seperti makan. minum, pakaian dan papan atau tempat berteduh. Sampai dengan kebutuhan psykologis seperti memperoleh penghargaan diri, mendapatkan teman bicara, merasakan suasana yang tenang, bergairah, dan sebagainya. Teori ini dikemukakan oleh Abraham Maslow yang disebutnya sebagai "Teori Hierarkhi Kebutuhan". Kebutuhankebutuhan tersebut akan muncul baik secara alamiah ataupun nonalamiah (sosial kemasyarakatan). 


\section{Pemanfaatan Teknologi Informasi}

Dalam penelitian ini memanfaatkan teknologi informasi dalam proses belajar dapat disebut sebagai suatu usaha pemanfaatan teknologi informasi untuk kebutuhan belajar siswa.

Istilah teknologi informasi mengandung pengertian yang sangat luas, sehingga banyak pakar yang menguraikan tentang definisi teknologi informasi dari berbagai sudut pandang. Salah satu definisi yang cukup dapat diterima banyak pihak adalah teknologi informasi merupakan suatu jenis belajar mengajar yang memungkinkan tersampaikannya bahan ajar ke siswa dengan menggunakan media belajar.

\section{h. Indikator Penelitian}

\section{Perilaku Belajar}

$\checkmark$ Innovative school

$\checkmark$ Mutu belajar

$\checkmark$ Produktivitas

$\checkmark$ Efisiensi

$\checkmark$ Akses

$\checkmark \quad$ Sikap positif

\section{Motivasi Belajar}

$\checkmark$ E-education

$\checkmark$ Maksimalitas pembelajaran

$\checkmark$ Lahirnya paradigm baru dalam pembelajaran

$\checkmark \quad$ Kebutuhan pasar kerja

\section{Pemanfaatan Teknologi Informasi}

$\checkmark$ Penyebaran informasi

$\checkmark \quad$ Penyajian materi secara logis

$\checkmark$ Menjadi partner guru dalam belajar mengajar

$\checkmark \quad$ Sumber belajar lebih menarik minat

$\checkmark$ Pencapaian sasaran

$\checkmark$ Mengatasi hambatan

$\checkmark$ Merangsang sasaran belajar

$\checkmark \quad$ Membantu sasaran belajar

$\checkmark \quad$ Mempermudah penyampaian bahan

$\checkmark$ Mempermudah penerimaan informasi

$\checkmark$ Mendorong keingintahuan

$\checkmark$ Pengiriman pesan

$\checkmark$ Fokus pada pembelajaran

$\checkmark$ Meningkatkan kemampuan belajar

$\checkmark$ Meningkatkan motivasi

$\checkmark$ Mengurangi ketergantungan

$\checkmark$ Efisiensi waktu 


\section{Berperan penuh dalam proses belajar}

i. Metode Pengumpulan Data

Sesuai dengan permasalahan dan tujuan penelitian yang ingin dicapai, penelitian ini menggunakan metode survei dengan teknik analisis korelasi. Teknik korelasional adalah suatu proses mengkaji ada tidaknya hubungan asosiatif dan fungsional atau memperkirakan secara sistematis tentang apa yang paling mungkin terjadi di masa yang akan datang berdasarkan informasi masa lalu dan sekarang yang dimiliki agar kesalahannya dapat diperkecil ${ }^{10}$. Dalam penelitian untuk memperoleh data tentang pemanfaatan teknologi informasi, motivasi belajar siswa terhadap perilaku belajar siswa SMK di Kota Manado akan digunakan tabel, angka-angka, simbol serta angket sebagai pengumpul data yang semua itu merupakan ciri khas penelitian kwantitatif.

\section{j. Teknik Pengujian Hipotesis}

Selanjutnya pengujian hipotesis penelitian dilakukan dengan korelasi Pearson Product Moment (PPM). Korelasi ini dikemukakan oleh Karl Pearson tahun 1990. Kegunaannya untuk mengetahui derajat hubungan antara variabel bebas (independent) dengan variabel terikat ${ }^{11}$ (dependent). Semua input dan analisa data akan dilakukan dengan bantuan program SPSS 16 for Windows 2007.

Hipotesis 1, 2, dan 3 dengan menggunakan rumus korelasi sederhana dan korelasi ganda sebagaimana berikut:

Rumus Korelasi Sederhana

Rumus Korelasi Ganda

$$
r x y=\frac{n\left(\sum X Y\right)-\left(\sum X\right) \cdot\left(\sum Y\right)}{\sqrt{\left\{n \cdot \sum X^{2}-\left(\sum Y\right)^{2}\right\} \cdot\left\{n \cdot \sum Y^{2}-\left(\sum Y^{2}\right)\right\}}}
$$

$$
r x 1 . x 2 . y=\sqrt{\frac{r_{x 1 . y}^{2}+r^{2}{ }_{x 1 . y}-2\left(r_{x 1 . y}\right) \cdot\left(r_{x 2 . y}\right) \cdot\left(r_{x 1 . x 2}\right)}{1-r_{x 1 . x 2}^{2}}}
$$

Korelasi PPM dilambangkan dengan (r) dengan ketentuan nilai 9 tidak lebih dari harga $(-1 \leq \mathrm{r} \leq+1)$. Apabila $\mathrm{r}=-1$ artinya korelasi negatif sempurna; $\mathrm{r}=0$ artinya tidak ada korelasi; dan $\mathrm{r}=1$ berarti korelasinya sangat kuat. Sedangkan arti harga $r$ akan dikonsultasikan dengan Tabel Interpretasi Nilai sebagai berikut:

${ }^{10}$ Riduwan dan Engkos Ahmad Kuncoro, Cara Menggunakan dan Memaknai Analisis Jalur, (Bandung : Alfabeta, 2007), h. 83.

11 Ibid, h. 61. 
Jurnal Iqra' Vol.3. No.1, Januari - Juni 2009

Tabel 3.3

Interpretasi Nilai $\mathbf{r}$

\begin{tabular}{|c|c|}
\hline Interval Koefisien & Tingkat Hubungan \\
\hline $0,80-1,000$ & Sangat Kuat \\
\hline $0,60-0,799$ & Kuat \\
\hline $0,40-0,599$ & Cukup Kuat \\
\hline $0,20-0,399$ & Rendah \\
\hline $0,00-0,199$ & Sangat Rendah \\
\hline
\end{tabular}

Sumber : Riduwan \& Engkos Acmad Kuncoro, (2007:62)

Besar kecilnya variabel $\mathrm{X}$ terhadap $\mathrm{Y}$ dapat ditentukan dengan rumus koefisien determinan sebagai berikut:

$$
\mathrm{KP}=\mathrm{r}^{2} \times 100 \%
$$

Keterangan :

$\mathrm{KP}=$ Nilai Koefisien Determinan

$\mathrm{r} \quad=$ Nilai Koefisien Korelasi

Pengujian signifikansi yang berfungsi apabila peneliti ingin mencari makna generalisasi dari hubungan variabel X terhadap Y, maka hasil korelasi PPM tersebut diuji dengan uji signifikansi sebagai berikut:

$\mathrm{H} 0=$ Variabel $\mathrm{X}$ berhubungan secara signifikan dengan variabel $\mathrm{Y}$

$\mathrm{Ha}=$ Variabel $\mathrm{X}$ tidak berhubungan secara signifikan dengan variabel $\mathrm{Y}$

Dasar Pengambilan Keputusan:

- Jika nilai probabilitas 0,05 lebih kecil atau sama dengan nilai probabilitas Sig atau [0,05 $\leq$ sig], maka H0 diterima dan Ha ditolak artinya signifikan.

- Jika nilai probabilitas 0,05 lebih besar atau sama dengan nilai probabilitas Sig atau [0,05 $\geq$ sig], maka H0 ditolak dan Ha diterima artinya tidak signifikan. 


\section{Hasil Penelitian}

\section{Hasil Penelitian}

Tabel Hasil Olahan SPSS 16 for windows

\begin{tabular}{|cc|c|c|c|}
\hline & & $\begin{array}{c}\text { Pemanfaatan } \\
\text { Teknologi } \\
\text { Informasi }\end{array}$ & $\begin{array}{c}\text { Motivasi } \\
\text { Belajar }\end{array}$ & $\begin{array}{c}\text { Perilaku } \\
\text { Belajar }\end{array}$ \\
\hline \begin{tabular}{ccc|c|} 
Pemanfaatan Teknologi \\
Informasi
\end{tabular} & Pearson Correlation & 1 & $.472^{* *}$ & $.538^{* *}$ \\
& Sig. (2-tailed) & $\mathrm{N}$ & .000 & .000 \\
& Pearson Correlation & $.472^{* *}$ & 1 & 84 \\
\hline Motivasi Belajar & Sig. (2-tailed) & .000 & & $.802^{* *}$ \\
& $\mathrm{~N}$ & 84 & 84 & 84 \\
\hline Perilaku Belajar & Pearson Correlation & $.538^{* *}$ & $.802^{* *}$ & 1 \\
& Sig. (2-tailed) & .000 & .000 & 84 \\
\hline
\end{tabular}

**. Correlation is significant at the 0.01 level (2-tailed).

\section{Model Summary Korelasi R $\mathbf{Y}_{\mathbf{X} 1 \mathrm{X} 2}$}

\begin{tabular}{|c|c|c|c|c|c|c|c|c|c|}
\hline \multirow[b]{2}{*}{ Model } & \multirow[b]{2}{*}{$\mathrm{R}$} & \multirow[b]{2}{*}{$\begin{array}{c}\mathrm{R} \\
\text { Square }\end{array}$} & \multirow[b]{2}{*}{$\begin{array}{l}\text { Adjusted R } \\
\text { Square }\end{array}$} & \multirow[b]{2}{*}{$\begin{array}{l}\text { Std. Error of } \\
\text { the Estimate }\end{array}$} & \multicolumn{5}{|c|}{ Change Statistics } \\
\hline & & & & & $\begin{array}{c}\text { R Square } \\
\text { Change }\end{array}$ & F Change & df1 & df2 & $\begin{array}{c}\text { Sig. F } \\
\text { Change }\end{array}$ \\
\hline 1 & $.822^{\mathrm{a}}$ & .676 & .668 & 6.91902 & .676 & 84.526 & 2 & 81 & .000 \\
\hline
\end{tabular}

a. Predictors: (Constant), Motivasi Belajar, Pemanfaatan Teknologi Informasi

\section{a. Hasil Pengujian Hipotesis 1}

\begin{tabular}{|c|c|c|c|}
\hline Hubungan antar Variabel & Korelasi & Nilai & Ket. \\
\hline X1 dengan Y & $\mathrm{r}_{\mathrm{yx} 1}$ & 0,538 & $\begin{array}{c}\text { Terima H0 Artinya } \\
\text { X1 berhubungan } \\
\text { signifikan dengan Y }\end{array}$ \\
$\begin{array}{c}\text { Hubungan Pemanfaatan Teknologi } \\
\text { Informasi dengan Perilaku Belajar }\end{array}$ & & & \\
\hline
\end{tabular}

Sumber : Diolah dari Tabel Hasil SPSS for windows 
Berdasarkan Tabel di atas hasil korelasi bahwa besarnya hubungan pemanfaatan teknologi informasi (X1) dengan perilaku belajar (Y) yang dihitung dengan koefisien korelasi adalah 0,538 atau $\left(\mathrm{r}_{\mathrm{YX} 1}=0,538\right)$. Hal ini menunjukkan hubungan yang kuat antara pemanfaatan teknologi informasi dengan perilaku belajar.

Pengaruh pemanfaatan teknologi informasi terhadap perilaku belajar adalah sebesar $\mathrm{KP}=\mathrm{r}^{2} \times 100 \%=0,538^{2} \times 100 \%=28,94 \%$. Maknanya pengaruh $28,94 \%$ variabel perilaku belajar dijelaskan oleh variabel pemanfaatan teknologi informasi dan sisanya $71,06 \%$ ditentukan oleh variabel lain yang tidak dapat dijelaskan dalam penelitian ini.

\section{Hasil Pengujian Hipotesis 2}

\begin{tabular}{|c|c|c|c|}
\hline Hubungan antar Variabel & Korelasi & Nilai & Ket. \\
\hline $\begin{array}{c}\text { X2 dengan Y } \\
\text { Hubungan Motivasi Belajar dengan } \\
\text { Perilaku Belajar }\end{array}$ & $\mathrm{r}_{\mathrm{y} \times 2}$ & 0,802 & $\begin{array}{c}\text { Terima H0 Artinya } \\
\text { X2 berhubungan } \\
\text { signifikan dengan Y }\end{array}$ \\
\hline
\end{tabular}

Sumber : Diolah dari Tabel Hasil SPSS for windows

Berdasarkan Tabel di atas hasil korelasi bahwa besarnya hubungan motivasi belajar (X2) dengan perilaku belajar (Y) yang dihitung dengan koefisien korelasi adalah atau ( $\mathrm{r}_{\mathrm{YX} 1}$ $=0,802$ ). Hal ini menunjukkan hubungan yang kuat antara motivasi belajar dengan perilaku belajar.

Pengaruh motivasi belajar terhadap perilaku belajar adalah sebesar $\mathrm{KP}=\mathrm{r}^{2} \times 100 \%$ $=0,802^{2} \times 100 \%=64,32 \%$. Maknanya pengaruh $64,32 \%$ variabel perilaku belajar ini dijelaskan oleh variabel motivasi belajar dan sisanya $35,68 \%$ ditentukan oleh variabel lain yang tidak dapat dijelaskan dalam penelitian ini.

\section{Hasil Pengujian Hipotesis 3}

\begin{tabular}{|c|c|c|c|}
\hline Hubungan antar Variabel & Korelasi & Nilai & Ket. \\
\hline $\begin{array}{c}\text { X1 dan X2 dengan Y } \\
\text { Hubungan secara bersama }\end{array}$ & $\mathrm{R}_{\mathrm{y} \times 1 \times 2}$ & 0,676 & $\begin{array}{c}\text { Terima H0 Artinya } \\
\text { X1 \& X2 } \\
\text { berhanfaatan teknologi informasi dan } \\
\text { Motivasi Belajar dengan Perilaku Belajar }\end{array}$ \\
& & & $\begin{array}{c}\text { signifikan secara } \\
\text { bersama-sama } \\
\text { dengan Y }\end{array}$ \\
\hline
\end{tabular}

Sumber : Diolah dari Tabel Hasil SPSS for windows

Berdasarkan Tabel Model Summary Korelasi Ganda $\mathrm{R}_{\mathrm{YX} 1 \mathrm{X} 2}$ terdapat $\mathrm{R}$ square adalah 0,676 (hasil pengkuadratan dari koefisien korelasi 0,822 atau $0,822^{2}$ ). Hal ini 
menunjukkan hubungan yang sangat kuat antara pemanfaatan teknologi informasi (X1) dan motivasi belajar (X2) secara simultan terhadap perilaku belajar (Y). R square dapat disebut koefisien determinasi yang dalam hal ini berarti 67,6\%. Maknanya pengaruh 67,6\% variabel perilaku belajar (Y) ini dijelaskan oleh variabel pemanfaatan teknologi informasi (X1) dan motivasi belajar (X2) dan sisanya 32,4\% dapat dijelaskan oleh sebab lain. Selanjutnya, untuk mengetahui signifikansi korelasi ganda yaitu dengan membandingkan antara nilai probabilitas 0,05 dengan nilai probabilitas sig. Ternyata $\alpha=0,05$ lebih besar dari nilai sig atau $[0,05>0,000]$, maka $\mathrm{H} 0$ diterima dan Ha ditolak. Artinya pemanfaatan teknologi informasi (X1) dan motivasi belajar (X2) berhubungan secara simultan dan signifikan dengan perilaku belajar (Y).

\section{Pembahasan}

\section{Hipotesis 1}

Hasil korelasi besarnya hubungan pemanfaatan teknologi informasi (X1) dengan perilaku belajar (Y) yang dihitung dengan koefisien korelasi adalah 0,538 atau $\left(\mathrm{r}_{\mathrm{YX} 1}=\right.$ 0,538). Hal ini menunjukkan hubungan yang kuat antara pemanfaatan teknologi informasi dengan perilaku belajar.

Pengaruh pemanfaatan teknologi informasi terhadap perilaku belajar adalah sebesar $\mathrm{KP}=\mathrm{r}^{2} \times 100 \%=0,538^{2} \times 100 \%=28,94 \%$. Maknanya pengaruh $28,94 \%$ variabel perilaku belajar dijelaskan oleh variabel pemanfaatan teknologi informasi dan sisanya 71,06 $\%$ ditentukan oleh variabel lain yang tidak dapat dijelaskan dalam penelitian ini.

\section{Hipotesis 2}

Hasil korelasi besarnya hubungan motivasi belajar (X2) dengan perilaku belajar (Y) yang dihitung dengan koefisien korelasi adalah atau $\left(\mathrm{r}_{\mathrm{YX} 1}=0,802\right)$. Hal ini menunjukkan hubungan yang kuat antara motivasi belajar dengan perilaku belajar.

Pengaruh motivasi belajar terhadap perilaku belajar adalah sebesar $\mathrm{KP}=\mathrm{r}^{2} \mathrm{x} 100 \%$ $=0,802^{2} \times 100 \%=64,32 \%$. Maknanya pengaruh $64,32 \%$ variabel perilaku belajar ini dijelaskan oleh variabel motivasi belajar dan sisanya 35,68\% ditentukan oleh variabel lain yang tidak dapat dijelaskan dalam penelitian ini.

\section{Hipotesis 3}

Model Summary Korelasi Ganda $\mathrm{R}_{\mathrm{YX} 1 \mathrm{X} 2}$ terdapat R square adalah 0,676 (hasil pengkuadratan dari koefisien korelasi 0,822 atau $0,822^{2}$ ). Hal ini menunjukkan hubungan yang sangat kuat antara pemanfaatan teknologi informasi (X1) dan motivasi belajar (X2) secara simultan terhadap perilaku belajar (Y). R square dapat disebut koefisien determinasi yang dalam hal ini berarti 67,6\%. Maknanya pengaruh 67,6\% variabel perilaku belajar (Y) ini dijelaskan oleh variabel pemanfaatan teknologi informasi (X1) dan motivasi belajar (X2) dan sisanya 32,4\% dapat dijelaskan oleh sebab lain. Selanjutnya, untuk mengetahui signifikansi korelasi ganda yaitu dengan membandingkan antara nilai probabilitas 0,05 dengan nilai probabilitas sig. Ternyata $\alpha=0,05$ lebih besar dari nilai sig atau $[0,05>0,000]$, maka H0 diterima dan Ha ditolak. Artinya pemanfaatan teknologi informasi (X1) dan motivasi belajar (X2) berhubungan secara simultan dan signifikan dengan perilaku belajar (Y). 
Jurnal Iqra' Vol.3. No.1, Januari - Juni 2009

\section{Kesimpulan}

Secara teoritis pemanfaatan teknologi informasi berhubungan dengan perilaku belajar siswa. Dalam penelitian ini hal tersebut teruji sehingga dapat dikatakan bahwa kontribusi pemanfaatan teknologi informasi untuk kasus siswa SMK di Kota Manado pemanfaatan teknologi informasi memiliki kontribusi yang besar dalam hal perilaku belajar siswa.

Secara teoritis motivasi belajar siswa berhubungan dengan perilaku belajar siswa. Dalam penelitian ini hal tersebut teruji sehingga dapat dikatakan bahwa kontribusi motivasi belajar untuk siswa SMK di Kota Manado menunjukkan bahwa dengan motivasi belajar yang besar dapat meningkatkan perilaku belajar siswa.

Pemanfaatan teknologi informasi dan motivasi belajar berhubungan dengan secara bersama-sama dengan perilaku belajar siswa. Dalam penelitian bahwa pemanfaatan teknologi informasi bersama-sama dengan motivasi belajar menjadi daya dorong yang besar terhadap perilaku belajar siswa.

\section{Daftar Pustaka}

\section{A. Buku}

Arikunto, Suharsimi, Prosedur Penelitian Suatu Pendekatan Praktek, Jakarta : Rineka Cipta, 2004

Cushway, Barry \& Derek Lodge, Perilaku dan Desain Organisasi, Jakarta : Alex Komputindo, 1993

Danim, Sudarwan, Inovasi Pendidikan, Pustaka Setia, 2002

Kambey, Daniel C., Manajemen Sumber Daya Manusia, cet. Pertama, Manado : Yayasan Triganesa Nusantara, 1999

Mangkunegara, Anwar Prabu Perilaku dan Budaya organisasi, Rerfika Aditama 2005.

Riduwan dan Engkos Ahmad Kuncoro, Cara Menggunakan dan Memaknai Analisis Jalur, Bandung: Alfabeta, 2007

Robbins, Stephen P. \& Mary Coulter, Manajemen, jilid 2, alih bahasa Harry Slamet, Edisi VIII, PT Indeks , 2007. Indeks, 2006. Perilaku Organisasi, alih bahasa Ahmad Fauzi, Edisi X, Jakarta : PT. 
Abdul Haris Abdullah - Pengaruh Pemanfaatan Teknologi......

\section{B. Media Online}

http://www.indonesia.go.id/id - REPUBLIK INDONESIA Powered by Joomla Generated: 25 June, 2008.

http://media.diknas.go.id/media/dokument/5448.pdf.

http://re-searchengines.com/art05-94.html.

http://www.digilib.ui.edu/opac/ themes/libri2/detail.jsp?id 